\title{
Thyroid status in children with steroid sensitive Nephrotic syndrome
}

\author{
Imalke Kankananarachchi, U K Jayantha, A L A Madhuranga, \\ Faculty of Medicine, University of Ruhuna
}

Abstract

\section{Introduction:}

Nephrotic syndrome (NS) is one of a major illness in childhood which needs prolonged immunosuppressive therapy due to its relapsing nature. Thyroid hormones and thyroxin-binding globulin (TBG) are known to lose in patients with NS. The main objectives of this research was to study the thyroid profile among the children with nephrotic syndrome during nephrosis and remission.

\section{Methods:}

An observational analytical study was carried out among total of 65 children with NS who were attending to University Nephrology Clinic, Teaching Hospital Karapitiya. Demographic details of patients and their relevant clinical details were obtained by an interviewer administered questionnaire. Blood for free T4, TSH, serum albumin and cholesterol were taken together and kept in $-80 \mathrm{C}$ after separating serum.

\section{Results:}

There were 35 and 30 patients in remission and in relapses respectively. Out of all $55.4 \%(n=36)$ were males. The mean age in remission and relapse groups were 86.9 months \pm 42.0 and 85.73 months \pm 38.45 . The proportions of patients who were on prednisolone, cyclophosphamide and cyclosporine were $92.3 \%(n=60), 21.5 \%(n=14)$ and $3.1 \%(n=2)$. The mean TSH levels in remission group and relapse group were $1.99 \pm 1.02 \mathrm{mIU} / \mathrm{L}$ and $4.69 \pm 2.99 \mathrm{mIU} / \mathrm{L}$ respectively $(\mathrm{P}=<0.001)$. There was no statistical difference $(\mathrm{P}=0.36)$ in the mean free $\mathrm{T} 4$ level of the remission group $(1.084 \pm 0.50) \mathrm{ng} / \mathrm{dL}$ compared to that of the relapse group $(1.23 \pm 0.74) \mathrm{ng} / \mathrm{dL}$. In contrast, total protein and serum albumin levels were significantly lower in the relapse group whereas, serum cholesterol was significantly higher $(\mathrm{P}=0.001)$ in the remission group.

\section{Conclusion:}

In conclusion, though subclinical hypothyroidism is evident in children with steroid sensitive nephrotic syndrome at the time of proteinuria, clinical or subclinical hypothyroidism do not exist among those who were in remission.

Keywords: Nephrotic, steroids, thyroid profile, children

Correspondence e mail: imalke462@gmail.com

ORCID ID: https://orcid.org/0000-0002-9351-2966

Copyright: This is an open-access article distributed under the terms of the Creative Commons Attribution License, which permits unrestricted use, distribution, and reproduction in any medium, provided the original author and source are credited (CC BY 4.0)

\section{Introduction}

Nephrotic syndrome (NS) is characterized by proteinuria, hypoalbuminemia, edema, and hypercholestorelemia.1It is one of a major illness in childhood which needs prolonged immunosuppressive therapy due to its relapsing nature.
In patients with NS many other proteins are excreted in the urine in addition to albumin. Thyroid hormones and thyroxin-binding globulin (TBG) are known to lose in patients with NS during relapses whichmay decrease the binding capacity of Thyroxine (T4) and triiodothyronine (T3).2Therefore, as a compensatory mechanism Thyroid 
Stimulating Hormone (TSH) would gone up in order to normalize thyroid status in the body. 3

Hypothyroidism is a known complication of steroid resistant nephrotic syndrome and it is a routine practice to screen for it.4The main objectives of this research were to study the thyroid profile among children with nephrotic syndrome during nephrosis and remission and to assess the relationship (if any) between serum albumin and thyroid profile in children with nephrotic syndrome.

\section{Methods}

An observational analytical study was carried out among total of 65 children with NS who were attending to University Nephrology Clinic, Teaching Hospital Karapitiya.Patients who fulfilled the standard definition of nephrotic syndrome presenting in first attack or relapse were included in one group whereas, those who were in remission included in another group. Consecutive sampling was carried out during the period of 2 years from July 2015 to June 2017. Measures were adopted to not to enrolled the same patient in two stages of the illness. Children with Steroid Resistance Nephrotic Syndrome were excluded. Socio-economic status of patients and their relevant clinical details were obtained by an interviewer administered questionnaire. Blood for free T4, TSH, serum Albumin and Cholesterol were taken together and kept in $-80 \mathrm{C}$ after separating serum. All samples were analysed using ELISA method in a single assay. Normal level was taken as Serum T4 $=0.80-2.00$ $\mathrm{ng} / \mathrm{dL}$ and $\mathrm{TSH}=0.70-5.97 \mathrm{mIU} / \mathrm{l}$. An ethical approval for the study was obtained from Ethical Review committee, Faculty of Medicine, University of Ruhuna.

\section{Results}

There were 35 and 30 patients in remission and in relapses respectively. Out of all $55.4 \%(n=36)$ were males. The mean age in remission and relapse groups were 86.9 months \pm 42.0 and 85.73 months \pm 38.45 with no statistical significance $(\mathrm{P}=0.9)$. The proportions of patients who were on prednisolone, cyclophosphamide and cyclosporine were $92.3 \%(\mathrm{n}=60), 21.5 \%(\mathrm{n}=14)$ and $3.1 \%$ $(n=2)$. All of them were clinically euthyroid. Table 1 shows the different categories of patients with NS.

\section{Table 1 Category of the patient}

\begin{tabular}{lc}
\hline Category & Frequency \\
\hline First episode & $19\left(29.2^{\%} \%\right.$ \\
Infrequently Relapsing Steroid Sensitive Nephrotic Syndrome (IRSSNS) & $22(33.8 \%)$ \\
Frequently Relapsing Steroid Sensitive Nephrotic Syndrome (FRSSNS) & $07(10.8 \%)$ \\
Steroid Dependent Nephrotic Syndrome (SDNS) & $17(26.2 \%)$ \\
Total & $65(100 \%)$ \\
\hline
\end{tabular}

\section{Table 2 Thyroid profile and investigation results of children with steroid}

sensitive nephrotic syndrome

\begin{tabular}{llcc}
\hline \multicolumn{1}{c}{ Variable } & \multicolumn{1}{c}{ Group } & Mean \pm SD & P \\
\hline TSH (mIU/L) & Remission & $1.99 \pm 1.02$ & 0.001 \\
T4 (ng/dL) & Relapse & $4.69 \pm 2.99$ & 0.357 \\
Total Protein (g/L) & Remission & $1.084 \pm 0.50$ & 0.001 \\
& Relapse & $1.23 \pm 0.74$ & \\
Albumin (g/L) & Remission & $66.45 \pm 6.47$ & 0.001 \\
Globulin (g/L) & Relapse & $43.96 \pm 5.24$ & 0.133 \\
& Relapse & $41.68 \pm 4.84$ & \\
Cholesterol (mg/dL) & Remission & $20.71 \pm 5.4$ & 0.001 \\
& Relapse & $24.70 \pm 4.68$ & \\
& Remission & $23.10 \pm 3.50$ & \\
\end{tabular}


The mean TSH levels in remission group and relapse group were $1.99 \pm 1.02 \mathrm{mIU} / \mathrm{L}$ and $4.69 \pm 2.99 \mathrm{mIU} / \mathrm{L}$ respectively and which showed a statistical significance $(\mathrm{P}=<0.001)$. The TSH value in the relapse grouped ranged from $0.9 \mu \mathrm{mol} / \mathrm{L}$ to $10.00 \mathrm{umol} / \mathrm{L}$ and $40 \%$ $(n=12)$ of them had subclinical hypothyroidism, whereas none of the patients in the remission category had subclinical hypothyroidism. There was no statistical difference $(\mathrm{P}=0.36)$ in the mean free $\mathrm{T} 4$ level of the remission group $(1.084 \pm 0.50) \mathrm{ng} / \mathrm{dL}$ compared to that of the relapse group $(1.23 \pm 0.74) \mathrm{ng} / \mathrm{dL}$.

In contrast, total protein and serum albumin levels were significantly lower in the relapse group whereas, serum cholesterol was significantly higher $(\mathrm{P}=0.001)$ in the remission group. (Table 2) There was no difference in the level of globulin in between two groups $(\mathrm{p}=0.133)$.

\section{Discussion}

The main reason of thyroid function abnormalities in nephrotic syndrome is the urinary loss of TBG. Several studies have shown that in nephrotic syndrome, thyroxine level goes down with elevation of TSH. Afroz S et al in 2006 has done an observational study with prospective follow up of study subjects and which showed that the mean value of Thyroid stimulating hormone (TSH) was elevated in children with nephrotic syndrome. A significant increase in TSH level during nephrosis $(9.11 \pm 6.36$ vs. $4.2 \pm 3.6 \mathrm{MIU} / \mathrm{L}$, $\mathrm{p}=0.005)$ was found, which normalized during remission. 5 Similarly, studies done by Gatoo I, Sawant et al, Gilles et al and Igeles et al have demonstrated transient subclinical hypothyroidism during the nephroses. $6,7,8,9$

Findings of the present study is compatible with that of the aforementioned studies though the methodology was different because in this study two groups of patients who were in relapse and in remission were enrolled.

However, in this study, the mean TSH value of patients with proteinuria $(4.69 \pm 2.99)$ was comparatively lower than that of studies done by Gatoo I et al (11.65 \pm 6.71umol/L) and Afroz et al $(9.11 \pm 6.36)$ and free T3 level was not assessed since it a poor marker as well as the last test to become abnormal in children with hypothyroidism. 5,6

Study done by Choudry et al showed low free T4 levels in children with nephrotic syndrome (4.75 \pm 2.10$)$ compared to healthy subjects (8.24 \pm 1.25$) .10 \mathrm{In}$ contrast, the study done by Vidhi
Sahni et al in 2013 revealed that normal T4 level during nephrosis $(5.37 \pm 1.06)$ and during remission $(5.72 \pm 0.90)$ with high TSH during nephrosis which normalizes during remission.11 Findings of our research is similar to that of the latter study in which the mean T4 level remained within normal range in both remission $(1.084 \pm 0.50) \mathrm{ng} / \mathrm{dL}$ and relapse groups $(1.23 \pm 0.74) \mathrm{ng} / \mathrm{dL}$. In some studies patients with nephrotic syndrome were treated with thyroxine and showed better outcomes in achieving remission. 12

In addition,Ito et al, have demonstrated elevated urinary T4, T3 and TBG.13Similar finding was obtained by Kaptein et al in which high urinary levels of TBG, transthyretin and albumin were detected.14 Urinary investigations were not done in the present study due to economic constraints.

\section{Conclusion}

In conclusion, though subclinical hypothyroidism is evident in children with steroid sensitive nephrotic syndrome at the time of proteinuria, clinical or subclinical hypothyroidism do not exist among those were in remission. However, further studies are needed to assess thyroid function tests of children who have prolonged and recurrent episodes of proteinuria since it would affect their growth potential. Conflict of interestThe authors declare no conflict of interest. Acknowledgement The would thank children who participated in the study and their parents. Furthermore, we would like to thank Dr.Manjula Hettiarachchi, Dr.Eric de Zoysa, Mrs Keshanie Gamalath, Mrs Mala Jayalath, Mr. Tharindu Asiri, Mrs Neetha Udeni and the laboratory staff of the Nuclear Medicine Unit, Faculty of Medicine, and University of Ruhuna. 


\section{References}

1. Behrman RE, Kliegman RM, Jenson HB, editors, Nelson Text Book of Paediatrics 18th ed. Philadelphia: W B Saunders; 2008. .2201.

2. Schussler GC. The thyroxine-binding proteins. Thyroid. 2000; 10: 141-9.

3. Iglesias P, Diez JJ. Thyroid dysfunction and kidney disease. Europeon Journal of Endocrinology. 2009; 160:503-15.

4. Kapoor K, Saha A, Dubey NK. Subclinical no autoimmune hypothyroidism in children with steroid resistant nephritic syndrome. Clin Exp Nephrol. 2014; 18(1):113-7.

5. Afroz S, Khan AH, Roy DK. Thyroid function in children with nephrotic syndrome. Mymensingh Med J. 2011; 20(3):407-11.

6. Gattoo I, Aziz A, Latief M, Najar BA. Thyroid Function in Pediatric Nephrotic Syndrome: A Hospital Based Observational Study. International Journal. 2015; 3(5):500-5.

7. Sawant BU, Nadkarni GD, Thakare UR, Joseph LJ, Rajan MGR. Changes in lipid peroxidation and free radical scavengers in kidney of hypothyroid and hyperthyroid. Indian journal of experimental biology. 2003:1334-7.

8. Gilles R, den Heijer M, Ross AH, Sweep FC, Hermus AR, Wetzels JF. Thyroid function in patients with proteinuria. Netherlands J Med. 2008; 66(11):483-5.

9. Iglesias P, Diez JJ. Thyroid dysfunction and kidney disease. European J Endocrinol. 2009; 160:503-15.

10. Choudhury J. A study onthyroid function test in children with nephroticsyndrome. Int J Contemp Pediatr. 2016; 3:752-4.

11. Sahni V, Nanda S, Gehlawat V, Gathwala G. Hypothyroidism in nephrotic syndrome in children. J Dent Med Sci. 2014; 13:7-11.

12. Qing-yin Guo et al.Steroids combined with levothyroxine to treat children with idiopathic nephrotic syndrome. Pediatric Nephrol. 2014; 29:1033-1038

13. Ito S, Kano K, Ando T, Ichimura T. Thyroid function in children with nephrotic syndrome. Pediatr Nephrol. 1994; 8(4):412-5.

14. Kaptein EM, Hoopes MT, Praise M, Massry SG. TT3 metabolism in patients with nephrotic syndrome and normal GFR compared with normal subjects. Am J physiol. 1991; 260:E641-50. 